\title{
Effect of Equal Channel Angular Extrusion on Corrosion Behavior of Al-Mn ALLOY
}

\author{
Namahoot, Jutatip; Davenport, A.; Ambat, Rajan
}

Published in:

Meeting Abstracts - Electrochemical Society

Publication date:

2008

Document Version

Publisher's PDF, also known as Version of record

Link back to DTU Orbit

Citation (APA):

Namahoot, J., Davenport, A., \& Ambat, R. (2008). Effect of Equal Channel Angular Extrusion on Corrosion Behavior of Al-Mn ALLOY. In Meeting Abstracts - Electrochemical Society (pp. Abstract 605). The Electrochemical Society.

\section{General rights}

Copyright and moral rights for the publications made accessible in the public portal are retained by the authors and/or other copyright owners and it is a condition of accessing publications that users recognise and abide by the legal requirements associated with these rights.

- Users may download and print one copy of any publication from the public portal for the purpose of private study or research.

- You may not further distribute the material or use it for any profit-making activity or commercial gain

- You may freely distribute the URL identifying the publication in the public portal

If you believe that this document breaches copyright please contact us providing details, and we will remove access to the work immediately and investigate your claim 


\section{EFFECT OF EQUAL CHANNEL ANGULAR EXTRUSION ON CORROSION BEHAVIOUR OF Al-Mn ALLOY}

J. Namahoot ${ }^{\text {a }}$, A.J. Davenport ${ }^{\text {b }}$, R. Ambat ${ }^{\text {, }}$, A.Afseth ${ }^{d}$, and G.M. Scamans ${ }^{\mathrm{e}}$,

${ }^{a}$ Chemistry Department, Naresuan University, Muang, Phitsanuloke, 65000, Thailand

${ }^{\mathrm{b}}$ Metallurgy and Materials, The University of Birmingham,

Pritchatts Rd., Birmingham, B15 2TT, UK

\author{
${ }^{\mathrm{c}}$ Department of Manufacturing Engineering \\ and Management, \\ Technical University of Denmark, \\ DK-2800 Kgs. Lyngby, Denmark \\ ${ }^{\mathrm{d}}$ Novelis, CH-8212 Neuhausen, Switzerland \\ e Innoval Technology Ltd, Banbury, \\ Oxon OX16 1TQ, UK
}

The formation of a highly deformed layer at the surface of rolled aluminium alloy sheet results from shear deformation during rolling. Subsequent annealing leads to enhanced precipitation of fine intermetallic particles in the surface layers. (1-3) These layers have high electrochemical reactivity, in particular, a strong susceptibility to filiform corrosion. (2, 4-5) This deformed layer also has a detrimental effect on other types of localised corrosion. (6-8)

In order to understand the role of deformation on corrosion behaviour of Al-Mn alloy, an Al-1Mn-0.4Fe-0.3Si model alloy was deformed by Equal channel angular extrusion (ECAE) and followed by annealing. The die angle for the extrusion was $2 \phi=120^{\circ}$. The rods were pressed with a ram speed $40 \mathrm{~mm} / \mathrm{min}$ at room temperature. The cycle was repeated each time without any rotation between passes. Samples were pressed 3, 10 and 15 times. It was found that deformation by ECAE followed by annealing leads to an increase in the number and \% area of intermetallic particles.

The manganese content in the matrix of the alloy after different levels of ECAE processing and heat treatment was determined using thermoelectric power (TEP) measurements. The higher number of ECAE passes result in the $\% \mathrm{Mn}$ in solid solution decreasing as shown in Fig. 1.

Electrochemical measurements were carried out in $0.1 \mathrm{M} \mathrm{NaCl}$. ECAE deformed samples have a higher cathodic reactivity than the undeformed sample as shown in Fig. 2. Furthermore, the higher levels of deformation increased the cathodic reactivity resulting from the breakdown of intermetallic particles into smaller particles when deformed and precipitated more intermetallic particles on the surface after heat-treatment.

The anodic polarisation measurements were conducted in 0.1 M NaCl, pH 11.5. The passive current density was slightly higher for the 15 ECAE passes sample and the breakdown potential was slightly lower as shown in Fig. 3. Thus, 15 ECAE passes and subsequently annealed sample was more anodically active than the undeformed and annealed sample.

The corroded surfaces after anodic polarisation showed the localised corrosion (pitting) sites on the surface. The number of pitting sites on the undeformed sample is less than that on the deformed sample. These are related to the number of intermetallic particles on the surface. It has been suggested that the increased precipitation on the deformed samples causes a decrease in solute content (Mn) of the matrix, thus enhancing the anodic reactivity.

\section{References}

1. R. Ambat, A. J. Davenport, A. Afseth, and G. Scamans, Journal of the Electrochemical Society, 151, B53-B58 (2004).

2. A. Afseth, J. H. Nordlien, G. M. Scamans, and K. Nisancioglu, Corrosion Science, 43, 2093-2109 (2001).

3. A. Afseth, J. H. Nordlien, G. M. Scamans, and K. Nisancioglu, Corrosion Science, 43, 2359-2377 (2001).

4. H. Leth-Olsen, J. H. Nordlien, and K. Nisancioglu, Corrosion Science, 40, 2051-2063 (1998).

5. A. Afseth, J. H. Nordlien, G. M. Scamans, and K. Nisancioglu, Corrosion Science, 44, 2491-2506 (2002).

6. P. J. E. Forsyth, Materials Science and Technology, 14, 151-160 (1998).

7. X. Zhou, G. E. Thompson, and G. M. Scamans, Corrosion Science, 45, 1767-1777 (2003).

8. R. Ambat, J. Namahoot, G. M. Scamans, A. Afseth, and A. J. Davenport, in Aluminium Surface Science and Technology (ASST 2003) Proceedings, Bonn, Germany, H. Terryn, Editor. p. 396-401, (2003).

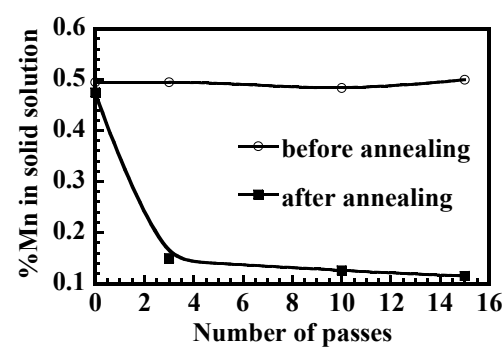

Fig. 1. \%Mn in solid solution of the undeformed and ECAE-deformed Al-1Mn-0.4Fe-0.3Si alloy.

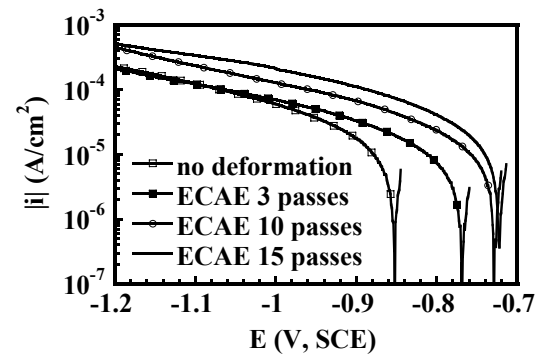

Fig. 2. Cathodic polarisation of Al-1Mn-0.4Fe-0.3Si with different numbers of ECAE passes and subsequent annealing in naturally $0.1 \mathrm{M} \mathrm{NaCl}$.

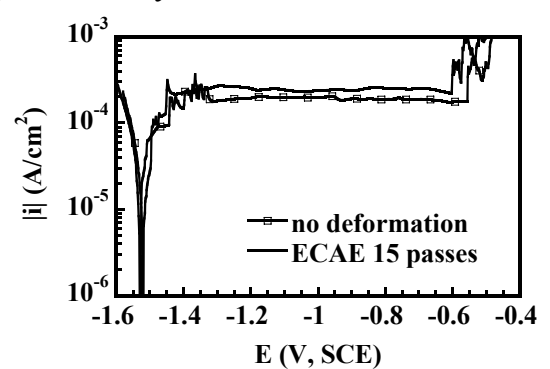

Fig. 3. Anodic polarisation of the undeformed and deformed (ECAE 15 passes) annealed samples of Al-1Mn$0.4 \mathrm{Fe}-0.3 \mathrm{Si}$ in naturally aerated $0.1 \mathrm{M} \mathrm{NaCl}, \mathrm{pH} 11.5$.

\section{Acknowledgement}

This project is funded by the Royal Thai Government. Alcan International supplies the alloys. The ECAE samples "were provided by Professor P. Prangnell at Manchester Materials Science Centre, Manchester. 